\title{
Classification of determinant factors of irrigated vegetable problems us- ing exploratory factor analysis in Swaida governorate, Syria
}

\author{
Maya AL-ABDALA ${ }^{1,2}$, Afraa SALLOWM ${ }^{3}$, Safwan ABOUASSAF ${ }^{1}$
}

Received May 26, 2021; accepted October 26, 2021.

Delo je prispelo 26. maja 2021, sprejeto 26. oktobra 2021

Classification of determinant factors of irrigated vegetable problems using exploratory factor analysis in Swaida governorate, Syria

Abstract: The objective of this research was to classify the determinant factors of irrigated vegetable problems and the amount of variance that is explained by each factor in Swaida Governorate/ Syria by using the Exploratory Factor Analysis. The research is based on the data which were collected through questionnaires that were obtained according to the opinions of farmers. It included questions about some of the social and economic characteristics of farmers, and the concerning problems related to irrigated agriculture by using multiple-choice questions (on a 3-point scale) during the 2019-2020 Based on a sample size of 92 farmers, representing $54.9 \%$ of the studied statistical community, and distributed randomly within the areas of spread of irrigated vegetable cultivation.. The results showed the success of using the exploratory factor analysis technique, using the Principal components methodology and Varimax in classifying six factors with an initial eigenvalues greater than one for each, and these factors are: agricultural technological progress, agricultural employment, sale outlets, natural conditions, prices, production requirements. These factors explained (13.21\%, $12.65 \%, 12.55 \%, 11.12 \%, 10.94 \%$, and $9.85 \%)$ of the total variance respectively, and together explained $70.33 \%$.

Key words: exploratory factor analysis; principal component; factors; Varimax; irrigated vegetables
Razvrstitev odločitvenih dejavnikov povezanih s problemi namakanja zelenjave $s$ faktorsko analizo na območju upravne enote Swaida, Sirija

Izvleček: Namen raziskave je bil s faktorsko analizo razvrstiti odločitvene dejavnike, povezane s problemom namakanja zelenjave, in določiti vpliv posameznega dejavnika na območju upravne enote Swaida v Siriji. Raziskava temelji na mnenjih kmetov, ki so bila pridobljena s pomočjo anketnih vprašalnikov. Ti so vključevali vprašanja o nekaterih socialnih in ekonomskih značilnostih kmetov in problemih z namakanjem, s katerimi se srečujejo. Anketirani so imeli možnost odgovoriti na vprašanja na 3-točkovni skali. Anketa, ki je potekala v obdobju 2019-2020, je temeljila na vzorcu 92 kmetov, kar je predstavljalo 54,9\% kmetov preučevane statistične regije. Anketiranci so bili izbrani naključno znotraj območja, kjer se pri gojenju zelenjave uporablja tudi namakanje. Rezultati so pokazali smiselnost uporabe faktorske analize. Z uporabo metode glavnih komponent in metode Varimax je bilo šest dejavnikov, z začetno lastno vrednostjo večjo od ena, razvrščenih glede na delež variabilnosti, ki jo pojasnjujejo. Ti dejavniki so: razvoj agrotehnike, zaposlitev v kmetijstvu, možnost prodaje, naravne danosti, cene, proizvodni stroški, pojasnjujejo pa13,21 \%, 12,65\%, $12,55 \%, 11,12 \%, 10,94 \%$, in 9,85 \% celotne variabilnosti oz. vsi skupaj pojasnjuejo 70,33 \% celotne variabilnosti.

Ključne besede: faktorska analiza; metoda glavnih komponent; dejavniki; Varimax; namakanje zelenjave

1 General Commission for Scientific Agricultural Research (GCSAR), Syria

2 Corresponding author, e-mail: mayaabdala6@gmail.com

3 Agricultural Economics, Faculty of Agriculture, University of Damascus, Syria 


\section{INTRODUCTION}

Agriculture is one of the important sectors in the Syrian economy, through its contribution to employing the labor force and covering the increasing food needs, especially in the current economic crisis and economic blockade. This study applies to the Swaida Governorate, where agriculture is the main production base and its ability to absorb the workforce in all steps of production until marketing, and thus contribute to solving the unemployment problem in the governor's countryside in particular. In spite of the fluctuation in its contribution to the local product, and the difficult economic conditions amid insecurity and the lack of available resources and weak implementation of rural development programs, the minimum level of self-sufficiency in agricultural products is sought.

Factor analysis is one of the important statistical methods that enabled researchers to classify scientific phenomena in multiple fields. It is used to find out the different correlations between data and to summarize it by identifying common characteristics. Therefore, factor analysis is one of the applications of the inductive approach, whereby a set of relationships can be traced back to common factors that describe and explain these relationships (Zeina, 2015). There are many studies that dealt with the exploratory factor analysis methodology in various fields such as agriculture, marketing, psychological sciences, and others, as it depends on the ordinal variables and listed according to a certain scale. Pavel and Moldovan (2019) in the study exploring the role of external factors determining local economic development in rural areas in Romania, based on data collected for the 398 communes from the North-West development region of Romania between 2007 and 2014, using exploratory factor analysis of principal components, where the results showed the location from urbanization and the presence of direct contact with European roads affect the level of local economic development and there is no impact of non-refundable investment programs in infrastructure in accelerating economic development.

Discovering the different dimensions of food security in relation with urban agriculture based on a sample of 360 families. The results of exploratory factor analysis identified three latent factors from 31 statements to which respondents indicated their level of agreement on a 5-point scale: the food availability and accessibility, adequate nutritional intake and reduction in fresh food expenditure. Contribution of each factor to the total variance were the following: $25.12 \%, 24.29 \%$, and $20.2 \%$ ) respectively, as together interpreted $69.61 \%$ (Rezai et al., 2016).

In order to exploratory factor analysis of barriers and problems affecting the development of nanotechnology in agriculture, four factors with eigenvalues greater than 1 , were extracted after orthogonal rotation using the varimax technique. These factors explained $74.40 \%$ of the total variance. According to extracted results, the financial support factor with the variance of 24.18 had the highest importance in the explanatory variables. After that, the Communication - Management, the cognitive learning and operating infrastructure factors were following it respectively (Ahmadi et al., 2013).

To assess the performance of Agri Clinic entrepreneurs promoted under the scheme on Agri Clinic and Agri Business Centers in India. Thus, an attempt has been made to evolve a set of factors influencing the entrepreneurial behavior through a data reduction process of factor analysis using Varimax. The factors include planning orientation, work orientation, personal efficacy, market orientation, location, business acumen, dynamism, service orientation, in-depth knowledge, achievement motivation, social networks, interest, internal control, marketing strategy and innovativeness. These factors collectively explained $86.91 \%$ of the total variance (Chandrashekar et al., 2012). There are many problems and constraints facing irrigated vegetable agriculture that pose great risks. These constraints lead to unstable yields. The most important of them are: the prevailing and fluctuating weather conditions, the spread of diseases and insects and the epidemically, the ineffectiveness of pesticides and fertilizers and their high prices, in addition to the problems related to marketing such as the lack of sales outlets or oversupply, and the monopoly of brokers. Therefore, it is necessary to identify the most important factors responsible for explaining the largest proportion of the total variation in the production of irrigated vegetable projects in Swaida Governorate by using the exploratory factor analysis methodology. The main goal is to classify the determining factors of the problems of irrigated vegetable cultivation into identifying the most important factors responsible for explaining the largest proportion of the total variation in the production of irrigated vegetable projects.

\section{MATERIALS AND METHODS}

\subsection{STUDY AREA}

The study was conducted in Swaida governorate, southern Syria during the 2020 agricultural season, in the places where irrigated crops spread. Knowing that the irrigated cropping patterns in Swaida governorate are divided between summer and winter crops and fruit trees. Where the area average of the irrigated pattern, 
excluding the fruit trees during 2016-2018 period was about 11008.33 Dunums (area unit $=1000 \mathrm{~m}^{2}$ ). The summer cropping pattern accounted $69.86 \%$ by about 7690 Dunums, including tomatoes, watermelons, melons, cucumbers, eggplant, pepper, etc., and the winter cropping pattern represented $30.14 \%$ by about 3318.33 Dunums, including wheat, peas, cauliflower, cabbage, onions, garlic and others (Ministry of Agriculture and Agrarian Reform Statistics, 2016-2018).

\subsection{DATABASE}

The study based on preliminary data through field visits the irrigated vegetable farmers who own wells. For the interviews, a structured questionnaire was designed with some of the social and economic characteristics of farmers and the concerning problems related to irrigated agriculture with multiple-choice questions using a three-point scale ranging from ( $1=$ there is no problem), ( $2=$ medium problem $),(3=$ strong problem) during 2019-2020 season in Swaida Governorate. Where the sample size is consisted of 92 observations represented $54.9 \%$ of the studied statistical community, based on a formula (Glenn, 1992) (Yamane, 1967):

$$
\mathrm{n}=\frac{\mathrm{N}}{1+\mathrm{N}(\mathrm{e})^{2}}
$$

Where: N_ The studied community (168 wells) worked for at least three consecutive years in the irrigation of vegetable crops (Agricultural Extension Department, 2020), e- Precision Level $\pm 7 \%$ Where Confidence Level is $95 \%$. were randomly distributed in the study area.

Data was processed using IBM Spss Statistics 26.

\subsection{STATISTICAL METHODS}

The study relied on descriptive analysis methods to describe the study variables such as means, percentage, charts, and exploratory factor analysis.

\subsubsection{Related concepts and terms}

Factor Analysis (FA): Is an interdependence technique whose primary purpose is to define the underlying structure among the variables in the analysis. Recently was developed originally for the analysis of scores on mental tests; however, the methods are useful in a much wider range of situations, for example, analyzing sets of tests of attitudes, sets of physical measurements, and sets of economic quantities (Anderson, 2003).
Principal Components Method (PCA): Is one of the most important methods of factor analysis. It can be used to analyze interrelationships among a large number of variables, and explain them in terms of their common underlying dimensions to find a way of condensing the information contained in a number of original variables into a smaller set of factors with a minimal loss of information by providing an empirical estimate of the structure of the variables considered (Hair et al., 2009). As long as PCA is used descriptively as convenient ways to summarize the relationships in a large set of observed variables, assumptions regarding the distributions of variables are not in Force (Tabachink \& Fidell, 2013).

Exploratory Factor Analysis (EPA): Is to discover the underlying structure of observed variables and identifies latent factors that explain the covariation among a set of variables. Ideally, the derived factors should consist of relatively homogenous variables, where each item loads strongly onto one factor and minimally on the other factor(s). It is assumed that each common factor affects every observed variable and that the common factors are either all correlated or uncorrelated (McDonald, 1985).

\subsubsection{Mathematical Models of EPA}

In the EPA model, (p) is the number of variables $\left(\mathrm{X}_{1}, \mathrm{X}_{2}, \ldots, \mathrm{X}_{\mathrm{p}}\right)$ and $(\mathrm{m})$ denotes the number of underlying factors $\left(\mathrm{F}_{1}, \mathrm{~F}_{2}, \ldots, \mathrm{F}_{\mathrm{m}}\right) . \mathrm{X}_{1}$ is the variable represented in Eigenvalue (latent) factors. Hence, this model assumes that there are $(\mathrm{m})$ underlying factors whereby each observed variable is a linear function of these factors together. This model intends to reproduce the maximum correlations:

$$
X j=\alpha j 1 F 1+\alpha j 2 F 2 \ldots \ldots \ldots \ldots \alpha j m m+\mathrm{e} j
$$

Where: $\mathrm{j}=1,2, \ldots, p$

The factor loadings are $\mathrm{a}_{\mathrm{j} 1}, \mathrm{a}_{\mathrm{i} 2}, \ldots, \mathrm{a}_{\mathrm{jm}}$ which denotes that $a_{j 1}$ is the factor loading of ( $j$ th) variable on the (1st) factor. The specific or unique factor is denoted by ej. The factor loadings give us an idea about how much the variable has contributed to the factor; the larger the factor loading the more the variable has contributed to that factor (Harman, 1976).

\subsubsection{Procedures in exploratory factor analysis}

Measure of sampling adequacy (MSA): Calculates both for the entire correlation matrix and for each individual variable evaluation the appropriateness of apply- 
ing factor analysis. Values above 0.5 for either the entire matrix or an individual variable indicate appropriateness (Hair et al., 2009).

Correlation matrix: When the data are appropriate, it is possible to create a correlation matrix by calculating the correlations between each pair of variables. As stated important information for the analysis in the correlation matrix are (Field, 2009): the variables have to be intercorrelated, but they should not correlate too highly (extreme multicollinearity and singularity). The coefficients less than 0.90 and suggested removing one of a pair of items with bivariate correlation scores greater than 0.8 ), the level of significance, the determinant (which should be greater than zero), and KMO and Bartlett's tests.

Tests of Bartlett sphericity and Kaiser-Meyer-Olkin (KMO): were used to determine the level of confidence that can be expected when using EFA on data (Hair et al., 2009). The Bartlett test of sphericity is based on the statistical distribution of Chi-square and tests the null hypothesis for the overall significance of all correlation within a correlation matrix, (i.e., no correlation between the variables). Levels of significance greater than 0.1 indicate that the data are not suitable for the treatment with the method in question; in this case, the null hypothesis can not be rejected. The KMO test presents normalized values (between 0 and 1) and shows the proportion of common variance of the variables, or what percentage of the variables is accounted for by common factors. To interpret the results, values close to 1 indicate that the factor analysis method is perfectly suited for data processing. On the other hand, values below 0.5 indicate the inadequacy of the method (Pituch \& Stevens, 2016).

Orthogonal Rotation: Is ordinarily used after extraction to maximize high correlations between factors and variables and minimize low ones. Numerous methods of rotation are available, but the most commonly used is varimax. Varimax is a variance-maximizing procedure. The goal of varimax rotation is to maximize the variance of factor loadings by making high loadings higher and lower ones lower for each factor. (Tabachink \& Fidell, 2013).

\subsubsection{Criteria for the number of factors to extract}

Eigenvalue (Latent root) Criterion: The most commonly used technique is the Eigenvalue criterion. Is simply to apply, the rationale the latent criterion is that any individual factor should account for the variance of at least as single variable if it is to be retained for interpretation. With PCA each variable contributes a value 1 root considered significant, all factors with roots less than 1 are insignificant and are disagreed (Thomapson, 2004).

Communalities: are the measure of the proportion of variance explained by the extracted factors, representing the amount of variance accounted by the factor solution for each variable, to assess whether the variables meet acceptable levels of explanation. The communalities should be more than 0.50 for each variable and more than 0.60 in average (Hair et al., 2009).

Scree Test: As (Cattell, 1966) proposed a graphical test for determining the number of factors. A scree plot graphs eigenvalue magnitudes on the vertical access, with eigenvalue numbers constituting the horizontal axis. Showing how to simplify the scree plot through dynamic graphic procedures when successive factor analyses are performed (Ledesma et al., 2015).

There are four steps for applying EPA which are involved briefly by Tighza (2012):

- Preparation of a correlation matrix between the measured variables.

- Extracting the initial factors and exploration of possible data reduction.

- Rotation to a terminal solution (find the interpretable factors).

- Naming the identifying factors.

\section{RESULTS AND DISCUSSION}

\subsection{CHARACTERISTICS OF THE STUDY SAMPLE POPULATION}

\subsubsection{Natural properties}

Geographical: The sample covered into three agricultural settlement zones according to the amount annual rainfall, the largest percentage was in the second zone with about $86.96 \%$, and covered three administrative regions, Swaida region was the largest - about 60.78 $\%$ Table (1).

Rainfall ratio: It ranged annually between a minimum of $125 \mathrm{~mm}$ and a maximum of $380 \mathrm{~mm}$, and an average amounted about $287.2 \mathrm{~mm}$.

Altitude: It ranged from a minimum of $650 \mathrm{~m}$ to a maximum of $1470 \mathrm{~m}$, and an average about $1004.5 \mathrm{~m}$.

\subsubsection{Economic characteristics}

Main job: An irrigated vegetable farming is $47.7 \%$ of the farmers. It is followed by $28.3 \%$ who are self-employed, $15.2 \%$ are employees in the public sector and 8.7 $\%$ have their own business.

Contribution to income: The cultivation of irrigated vegetables contributes about $53.21 \%$ of the family income, while other kinds of agriculture contribute about 
Table 1: Distribution of farmers according to the agricultural settlement zones and administrative regions in Swaida governorate during the 2020 agricultural season

\begin{tabular}{|c|c|c|c|c|c|c|}
\hline \multirow[b]{2}{*}{ First } & & \multicolumn{3}{|c|}{ Settlement Zones } & \multirow[b]{2}{*}{ Total } & \multirow[b]{2}{*}{$\%$} \\
\hline & & First & Second & Third & & \\
\hline \multirow{3}{*}{$\begin{array}{l}\text { Administrative } \\
\text { Regions }\end{array}$} & Salkad & 6 & 22 & 2 & 30 & 32.61 \\
\hline & Swaida & 4 & 52 & 0 & 56 & 60.87 \\
\hline & Shahba & 0 & 6 & 0 & 6 & 6.52 \\
\hline Total & & 10 & 80 & 2 & 92 & 100 \\
\hline$\%$ & & 10.87 & 86.96 & 2.17 & 100 & \\
\hline
\end{tabular}

Source: Survey results

$20.33 \%$, and only $26.47 \%$ income came from non-agriculture.

\subsubsection{Social Characteristics}

Age of the farmers: It ranged between 26 and 70 years as a min and max respectively, and about 46.4 years in average.

Experience: There was a variation in the farmers experience regarding producing of irrigated vegetables, which ranged from 1 year to 40 years, and reached an average of about 13.55 Years.

Educational levels: It ranged between the highest percentages of those with primary education (about 64 $\%)$, then about $20 \%$ of them with university education, and $14 \%$ with secondary education and only $2 \%$ were illiterate. Figure (1).

\subsection{THE PROBLEMS FACING FARMERS}

The results of the responses about relative frequency

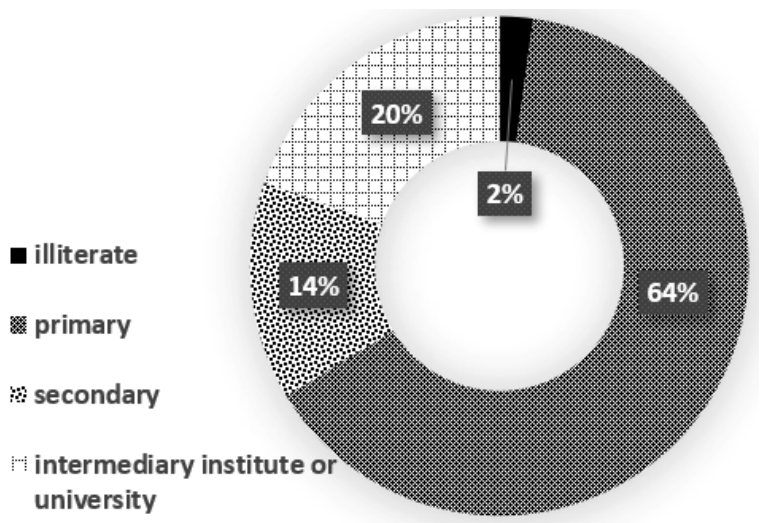

Figure 1: Percentage distribution of farmers according to educational level were used to analyze the main problems that effect on cultivation of irrigated vegetable where it was found that $98.9 \%$ of farmers emphasized the problem of high costs inputs, $83.7 \%$ State support for production requirements and $69.6 \%$ Infection with diseases and insects respectively are strong problems, Table (2).

\subsection{DETERMINE THE FACTORS RESPONSIBLE FOR THE LARGEST PROPORTION OF THE TOTAL VARIANCE IN THE PRODUCTION OF IRRIGATED VEGETABLES PROJECTS, THE RESULTS OF (EPA)}

\subsubsection{The first Step: Analysis of the correlation matrix between the measured variables}

According to Table (1) in the Appendix, the value of (MSA) appears in the diagonal cells of the variable (X8) equal to 0.341, which is less than 0.5 , therefore it is deleted and re-analyzed. The Re-analysis excluding the variable (x8) and showed the following results:

Correlation coefficients: they should not exceed 0.9 , as it is impossible to estimate the percentage of variance that the variables contribute to forming the extracted factors. Table (3) shows the inter-correlations matrix in the upper half, and the statistical significance in the lower half, which fulfills the condition.

The determinant of the matrix: which requires that the absolute value of the determinant must be greater than 0.0000, and it appears at the bottom of Table (3), Determinant $=.028$, meaning that the second condition is also fulfilled, and therefore the matrix does not involve the problem of exaggerated correlation between the variables.

Bartlett's Test of Sphericity: Table (4) shows the significance of the Bartlett test $(\mathrm{Sig}<0.00)$ and the acceptance of the alternative hypothesis and thus the matrix is not neutral (Identity Matrix), and there are 
some relationships between the variables that can be analyzed.

Kaiser-Meyer-Olkin (KMO(: Table (4) shows that the KMO value is equal to 0.586 and is greater than 0.5 , thus the reliability of the factors that will be obtained from the analysis, and that the sample size is sufficient.
Measure of Sampling Adequacy (MSA): The MSA values in the diagonal cells show that all correlation coefficients equal or exceed the value 0.5 , indicating that the level of correlation between each variable with other variables in the correlation matrix is sufficient for analyzing.

Table 2: Relative frequency of the responses to evaluate the characteristics related to the problems of irrigated vegetable production

\begin{tabular}{lllll}
\hline & & Ranking (\%) & \\
\cline { 2 - 4 } Variables & Problems & There Is No (1) & Medium (2) & Strong (3) \\
\hline X1 & Availability Of Manpower & 17.4 & 35.9 & 46.7 \\
X2 & Labor Efficiency & 12.0 & 53.3 & 34.8 \\
X3 & Infection With Diseases And Insects & 7.6 & 22.8 & 69.6 \\
X4 & Natural Disasters & 55.4 & 20.7 & 23.9 \\
X5 & Availability Of Inputs & 48.9 & 17.4 & 33.7 \\
X6 & High Costs Of Inputs & 1.1 & 98.9 \\
X7 & Effectiveness Of Inputs & 8.7 & 29.3 & 62.0 \\
X8 & State Support For Production Requirements & 2.2 & 14.1 & 83.7 \\
X9 & Vegetable Price Fluctuations & 6.5 & 30.4 & 63.0 \\
X10 & Brokers' Control & 10.9 & 27.2 & 62.0 \\
X11 & Low Selling Price & 7.6 & 13.0 & 79.3 \\
X12 & Disposing Of The Product & 52.2 & 21.7 & 26.1 \\
X13 & Availability Of Internal And External Markets & 50.0 & 22.8 & 27.2 \\
X14 & Providing Farmers With The Necessary Expertise & 57.6 & 18.5 & 23.9 \\
X15 & Availability Of Information About New Technologies & 63.0 & 16.3 & 20.7 \\
\hline
\end{tabular}

Source: Survey results

Table 3: Correlation Matrix between the measured variables (The Problems of Irrigated Vegetable in Swaida governorate during the 2020 agricultural season)

\begin{tabular}{|c|c|c|c|c|c|c|c|c|c|c|c|c|c|c|c|}
\hline & & $\mathrm{x} 1$ & $\mathrm{x} 2$ & $\mathrm{x} 3$ & $\mathrm{x} 4$ & $\mathrm{x} 5$ & $\mathrm{x} 6$ & $\mathrm{x} 7$ & x9 & $\mathrm{x} 10$ & $\mathrm{x} 11$ & $\mathrm{x} 12$ & $\mathrm{x} 13$ & x14 & x15 \\
\hline \multirow{14}{*}{ 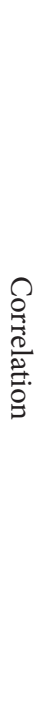 } & $\mathrm{x} 1$ & 1.00 & & & & & & & & & & & & & \\
\hline & $\mathrm{x} 2$ & 0.63 & 1.00 & & & & & & & & & & & & \\
\hline & $\mathrm{x} 3$ & 0.15 & 0.19 & 1.00 & & & & & & & & & & & \\
\hline & $\mathrm{x} 4$ & 0.04 & 0.13 & 0.31 & 1.00 & & & & & & & & & & \\
\hline & $\mathrm{x} 5$ & 0.16 & 0.00 & 0.03 & 0.15 & 1.00 & & & & & & & & & \\
\hline & $\mathrm{x} 6$ & 0.04 & 0.20 & 0.10 & -0.04 & -0.13 & 1.00 & & & & & & & & \\
\hline & $\mathrm{x} 7$ & 0.15 & 0.20 & 0.10 & 0.09 & 0.08 & 0.09 & 1.00 & & & & & & & \\
\hline & $\mathrm{x} 9$ & 0.02 & 0.11 & -0.01 & 0.14 & 0.28 & 0.27 & 0.17 & 1.00 & & & & & & \\
\hline & $\mathrm{x} 10$ & 0.22 & 0.13 & 0.02 & 0.09 & 0.18 & 0.08 & 0.07 & 0.30 & 1.00 & & & & & \\
\hline & $\mathrm{x} 11$ & 0.24 & 0.22 & 0.24 & 0.19 & -0.12 & 0.30 & 0.05 & 0.05 & 0.14 & 1.00 & & & & \\
\hline & $\mathrm{x} 12$ & 0.14 & 0.23 & 0.33 & 0.21 & 0.19 & 0.09 & 0.29 & 0.03 & -0.03 & 0.20 & 1.00 & & & \\
\hline & $\mathrm{x} 13$ & 0.21 & 0.31 & 0.23 & 0.22 & 0.15 & 0.10 & 0.16 & 0.12 & 0.13 & 0.19 & 0.58 & 1.00 & & \\
\hline & $\mathrm{x} 14$ & -0.12 & -0.06 & 0.09 & 0.17 & 0.16 & -0.17 & 0.17 & 0.03 & 0.09 & -0.04 & 0.23 & 0.14 & 1.00 & \\
\hline & x15 & -0.08 & -0.02 & 0.20 & 0.12 & 0.12 & -0.18 & 0.16 & 0.00 & 0.21 & -0.09 & 0.24 & 0.27 & 0.75 & 1.00 \\
\hline
\end{tabular}


Continued

\begin{tabular}{|c|c|c|c|c|c|c|c|c|c|c|c|c|}
\hline $\mathrm{x} 2$ & 0.00 & & & & & & & & & & & \\
\hline $\mathrm{x} 3$ & 0.08 & 0.04 & & & & & & & & & & \\
\hline $\mathrm{x} 4$ & 0.34 & 0.10 & 0.00 & & & & & & & & & \\
\hline $\mathrm{x} 5$ & 0.06 & 0.49 & 0.38 & 0.07 & & & & & & & & \\
\hline$x 6$ & 0.35 & 0.03 & 0.16 & 0.35 & 0.10 & & & & & & & \\
\hline $\mathrm{x} 7$ & 0.08 & 0.03 & 0.18 & 0.20 & 0.22 & 0.21 & & & & & & \\
\hline $\mathrm{x} 9$ & 0.43 & 0.14 & 0.48 & 0.10 & 0.00 & 0.00 & 0.05 & & & & & \\
\hline $\mathrm{x} 10$ & 0.02 & 0.11 & 0.42 & 0.19 & 0.04 & 0.23 & 0.25 & 0.00 & & & & \\
\hline x11 & 0.01 & 0.02 & 0.01 & 0.03 & 0.12 & 0.00 & 0.31 & 0.32 & 0.09 & & & \\
\hline x12 & 0.09 & 0.01 & 0.00 & 0.02 & 0.03 & 0.19 & 0.00 & 0.38 & 0.38 & 0.03 & & \\
\hline x13 & 0.02 & 0.00 & 0.01 & 0.02 & 0.07 & 0.18 & 0.06 & 0.12 & 0.12 & 0.03 & 0.00 & \\
\hline x14 & 0.13 & 0.29 & 0.20 & 0.05 & 0.06 & 0.06 & 0.05 & 0.38 & 0.19 & 0.36 & 0.01 & 0.10 \\
\hline x15 & 0.22 & 0.41 & 0.03 & 0.12 & 0.13 & 0.04 & 0.06 & 0.50 & 0.02 & 0.20 & 0.01 & 0.00 \\
\hline
\end{tabular}

a. Determinant $=.028$

Source: IBM Spss Statistics 26 Output /survey results

Table 4: KMO and Bartlett's Test

Kaiser-Meyer-Olkin Measure of Sampling Adequacy .586

Approx. Chi-Square

305.846

Bartlett's Test of Sphericity

Df

91

Sig.

.000

Source: IBM Spss Statistics 26 Output /survey results

Table 5: Measure of sampling adequacy (MSA) for the measured variables (The problems of irrigated vegetable)

\begin{tabular}{|c|c|c|c|c|c|c|c|c|c|c|c|c|c|c|c|}
\hline \multicolumn{16}{|c|}{ Anti-image Matrices } \\
\hline & & $\mathrm{x} 1$ & $\mathrm{x} 2$ & $\mathrm{x} 3$ & $\mathrm{x} 4$ & $\mathrm{x} 5$ & $\mathrm{x} 6$ & $\mathrm{x} 7$ & $\mathrm{x} 9$ & $\mathrm{x} 10$ & $\mathrm{x} 11$ & $\mathrm{x} 12$ & $\mathrm{x} 13$ & $\mathrm{x} 14$ & $\mathrm{x} 15$ \\
\hline \multirow{14}{*}{ 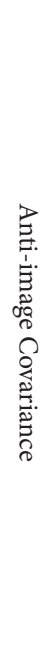 } & $\mathrm{x} 1$ & 0.50 & -0.31 & -0.04 & 0.07 & -0.15 & 0.08 & -0.05 & 0.09 & -0.12 & -0.10 & 0.02 & -0.01 & 0.03 & 0.03 \\
\hline & $\mathrm{x} 2$ & -0.31 & 0.51 & -0.02 & -0.06 & 0.11 & -0.09 & -0.05 & -0.06 & 0.03 & 0.03 & -0.02 & -0.08 & 0.00 & 0.00 \\
\hline & $\mathrm{x} 3$ & -0.04 & -0.02 & 0.75 & -0.21 & 0.00 & -0.07 & 0.02 & 0.03 & 0.05 & -0.10 & -0.13 & 0.05 & 0.09 & -0.12 \\
\hline & $\mathrm{x} 4$ & 0.07 & -0.06 & -0.21 & 0.79 & -0.07 & 0.12 & -0.01 & -0.07 & -0.03 & -0.11 & 0.01 & -0.07 & -0.08 & 0.05 \\
\hline & $\mathrm{x} 5$ & -0.15 & 0.11 & 0.00 & -0.07 & 0.74 & 0.10 & 0.03 & -0.21 & -0.07 & 0.15 & -0.11 & -0.02 & -0.06 & 0.03 \\
\hline & $\mathrm{x} 6$ & 0.08 & -0.09 & -0.07 & 0.12 & 0.10 & 0.74 & -0.03 & -0.20 & -0.04 & -0.17 & -0.04 & -0.01 & 0.02 & 0.06 \\
\hline & $\mathrm{x} 7$ & -0.05 & -0.05 & 0.02 & -0.01 & 0.03 & -0.03 & 0.85 & -0.12 & 0.00 & 0.03 & -0.15 & 0.05 & -0.03 & -0.03 \\
\hline & $\mathrm{x} 9$ & 0.09 & -0.06 & 0.03 & -0.07 & -0.21 & -0.20 & -0.12 & 0.73 & -0.18 & 0.02 & 0.06 & -0.05 & -0.02 & 0.04 \\
\hline & $\mathrm{x} 10$ & -0.12 & 0.03 & 0.05 & -0.03 & -0.07 & -0.04 & 0.00 & -0.18 & 0.75 & -0.11 & 0.10 & -0.02 & 0.06 & -0.14 \\
\hline & x11 & -0.10 & 0.03 & -0.10 & -0.11 & 0.15 & -0.17 & 0.03 & 0.02 & -0.11 & 0.74 & -0.06 & -0.05 & -0.06 & 0.08 \\
\hline & $\mathrm{x} 12$ & 0.02 & -0.02 & -0.13 & 0.01 & -0.11 & -0.04 & -0.15 & 0.06 & 0.10 & -0.06 & 0.53 & -0.27 & -0.06 & 0.02 \\
\hline & $\mathrm{x} 13$ & -0.01 & -0.08 & 0.05 & -0.07 & -0.02 & -0.01 & 0.05 & -0.05 & -0.02 & -0.05 & -0.27 & 0.56 & 0.09 & -0.11 \\
\hline & $\mathrm{x} 14$ & 0.03 & 0.00 & 0.09 & -0.08 & -0.06 & 0.02 & -0.03 & -0.02 & 0.06 & -0.06 & -0.06 & 0.09 & 0.39 & -0.27 \\
\hline & x15 & 0.03 & 0.00 & -0.12 & 0.05 & 0.03 & 0.06 & -0.03 & 0.04 & -0.14 & 0.08 & 0.02 & -0.11 & -0.27 & 0.34 \\
\hline
\end{tabular}




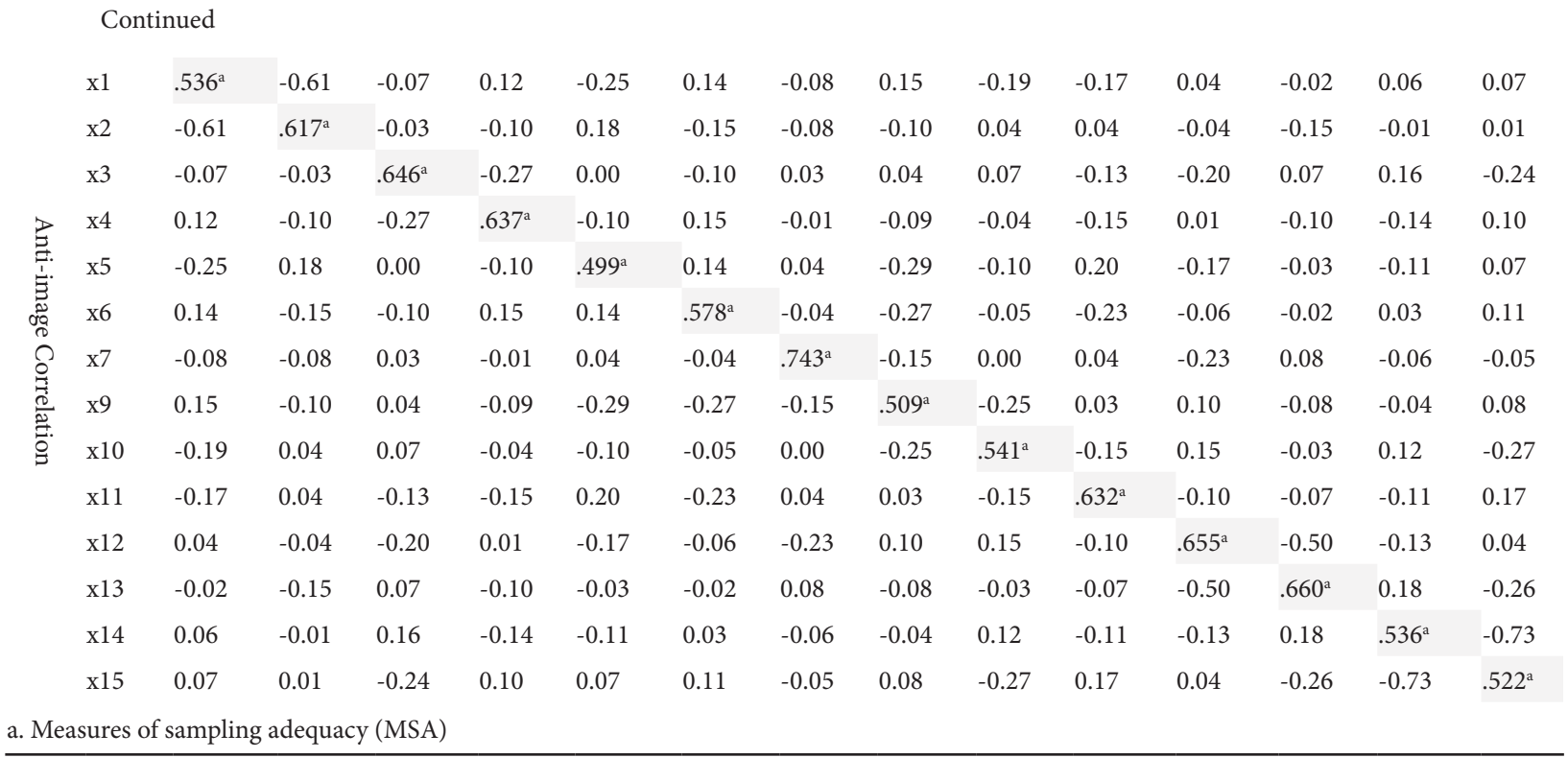

Source: IBM Spss Statistics 26 Output / survey results

\subsubsection{The second step: Extraction analysis}

Method: One of the statistical approaches in extracting factors is principal components analysis; the factors with eigenvalues (own values) $>1.0$ and factorial loads $>$ 0.4 were used as consideration criteria. The results were also combined with the orthogonal methods of rotation Varimax.

Detraining the extracted factors: Table (6) shows the number of each extracted factor with Eigenvalues, and percentage of variance and cumulative variance of each of the factors._Six factors with eigenvalues greater than 1 were extracted. Factors that influence the irrigated vegetable farming, according to factors loadings after orthogonal rotation using the Varimax were classified. These factors explained $70.33 \%$ of the total variance, and only less than $29.67 \%$ of variance were due to factors that were not identified through factor analysis. It is noticed that the rotation distributes the variance ratios among the factors in a relatively balanced manner and does not make it concentrated in the first factor or second factor, and this is evident by comparing column (9) in Table (6) where the ratios of interpretation of variances were reached from the total variance of each factor. For example; the first factor has the highest Eigenvalue equals 1.85 and the total explained variance equals $13.21 \%$.

The total explained variance for the first factor $=($ Eigenvalue $/$ the number of eigenvalues $) * 100=$ $=(1.85 / 14) * 100=13.21 \%$.
Commonalities: Table (7) shows the values of the communalities which is greater than 0.05 for each variable, and the average for all variables is 0.703 , greater than 0.60 . Thus, we have obtained the values of the explained variance for each variable, for example; as the extracted value of the variable $\mathrm{x}_{1}$ (availability of manpower) equals 0.848 of the variances in the variable values are explained by the common factors.

The Scree test: Is a heuristic graphic method that consists of:

a) Plotting the eigenvalues (y-axis) against the components (x-axis), and

b) Inspecting the shape of the resulting curve in order to detect the point at which the curve changes drastically.

The eigenvalues are plotted as a bold point within the graph, and successive values are connected by a line. Factor extraction should be stopped at the point where there is an "elbow", or leveling of the plot (Thomapson, 2004). This plot suggests that six factors should be extracted (Figure 2).

\subsubsection{The third step, rotation}

Table (8) shows the loading of the variables on the six factors before rotation and after orthogonal rotation by the Varimax method.

It is noticed that most of the items in the component matrix before rotation loaded on most of the factors. It is also showing a common loading in most of the items on 
Table 6: Total explained variance of each extracted factors with eigenvalues

\begin{tabular}{|c|c|c|c|c|c|c|c|c|c|}
\hline \multicolumn{10}{|c|}{ Total Variance Explained } \\
\hline \multirow{2}{*}{ 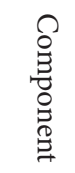 } & \multicolumn{3}{|c|}{ Initial Eigenvalues } & \multicolumn{3}{|c|}{ Extraction Sums of Squared Loadings } & \multicolumn{3}{|c|}{ Rotation Sums of Squared Loadings } \\
\hline & Total & $\begin{array}{l}\% \text { of } \\
\text { Variance }\end{array}$ & $\begin{array}{l}\text { Cumulative } \\
\%\end{array}$ & Total & $\begin{array}{l}\% \text { of } \\
\text { Variance }\end{array}$ & $\begin{array}{l}\text { Cumulative } \\
\%\end{array}$ & Total & $\begin{array}{l}\% \text { of } \\
\text { Variance }\end{array}$ & $\begin{array}{l}\text { Cumulative } \\
\%\end{array}$ \\
\hline 1 & 2.95 & 21.07 & 21.07 & 2.95 & 21.07 & 21.07 & 1.85 & 13.21 & 13.21 \\
\hline 2 & 2.10 & 14.98 & 36.05 & 2.10 & 14.98 & 36.05 & 1.77 & 12.65 & 25.87 \\
\hline 3 & 1.44 & 10.29 & 46.34 & 1.44 & 10.29 & 46.34 & 1.76 & 12.55 & 38.41 \\
\hline 4 & 1.23 & 8.81 & 55.14 & 1.23 & 8.81 & 55.14 & 1.56 & 11.12 & 49.53 \\
\hline 5 & 1.06 & 7.60 & 62.74 & 1.06 & 7.60 & 62.74 & 1.53 & 10.94 & 60.48 \\
\hline 6 & 1.06 & 7.59 & 70.33 & 1.06 & 7.59 & 70.33 & 1.38 & 9.85 & 70.33 \\
\hline 7 & 0.86 & 6.12 & 76.45 & & & & & & \\
\hline 8 & 0.70 & 5.01 & 81.45 & & & & & & \\
\hline 9 & 0.67 & 4.79 & 86.25 & & & & & & \\
\hline 10 & 0.63 & 4.48 & 90.73 & & & & & & \\
\hline 11 & 0.48 & 3.40 & 94.13 & & & & & & \\
\hline 12 & 0.35 & 2.50 & 96.64 & & & & & & \\
\hline 13 & 0.28 & 2.01 & 98.65 & & & & & & \\
\hline 14 & 0.19 & 1.36 & 100.00 & & & & & & \\
\hline Extrac & ion $\mathrm{Me}$ & d: Princip & mponent Ana & ysis & & & & & \\
\hline
\end{tabular}

Source: IBM Spss Statistics 26 Output /survey result

Table 7: Communalities (extracted value of variance) for the measured variables (The problems of irrigated vegetable)

\begin{tabular}{lll}
\hline & Initial & Extraction \\
\hline $\mathrm{x} 1$ & 1.000 & .848 \\
$\mathrm{x} 2$ & 1.000 & .730 \\
$\mathrm{x} 3$ & 1.000 & .548 \\
$\mathrm{x} 4$ & 1.000 & .645 \\
$\mathrm{x} 5$ & 1.000 & .750 \\
$\mathrm{x} 6$ & 1.000 & .734 \\
$\mathrm{x} 7$ & 1.000 & .507 \\
$\mathrm{x} 9$ & 1.000 & .762 \\
$\mathrm{x} 10$ & 1.000 & .721 \\
$\mathrm{x} 11$ & 1.000 & .614 \\
$\mathrm{x} 12$ & 1.000 & .754 \\
$\mathrm{x} 13$ & 1.000 & .562 \\
$\mathrm{x} 14$ & 1.000 & .798 \\
$\mathrm{x} 15$ & 1.000 & .872 \\
\hline
\end{tabular}

Extraction Method: Principal Component Analysis

Source: IBM Spss Statistics 26 Output /survey results the six factors, as most of the variables were of a high load on the first factor, meaning there is a clear absence in the balance of the loading on the extracted factors, which shows the difficulty in interpretation.

Whereas, after the rotation the variance explained by each factor was redistributed. As a change in the pattern of loading, up and down is observed on each factor, and a change in the percentage of explained variance, and it is noticed that the load values that are smaller than 0.6 are hidden and the variables are arranged according to the load, which makes the interpretation easier.

The factor matrix after rotation, which includes six factors. Where all the variables were loaded after rotation on the six factors, except the variable x11. Thus, according to extracted results, the six extracted factors will be named. Table (8).

Figure (3) shows a schematic representation of the rotation of the axes, an orthogonal rotation, meaning that the factors were rotated while maintaining them independent. Before rotation, all the factors were independent (not completely related), and the orthogonal rotation ensures that all the factors remain unrelated. 


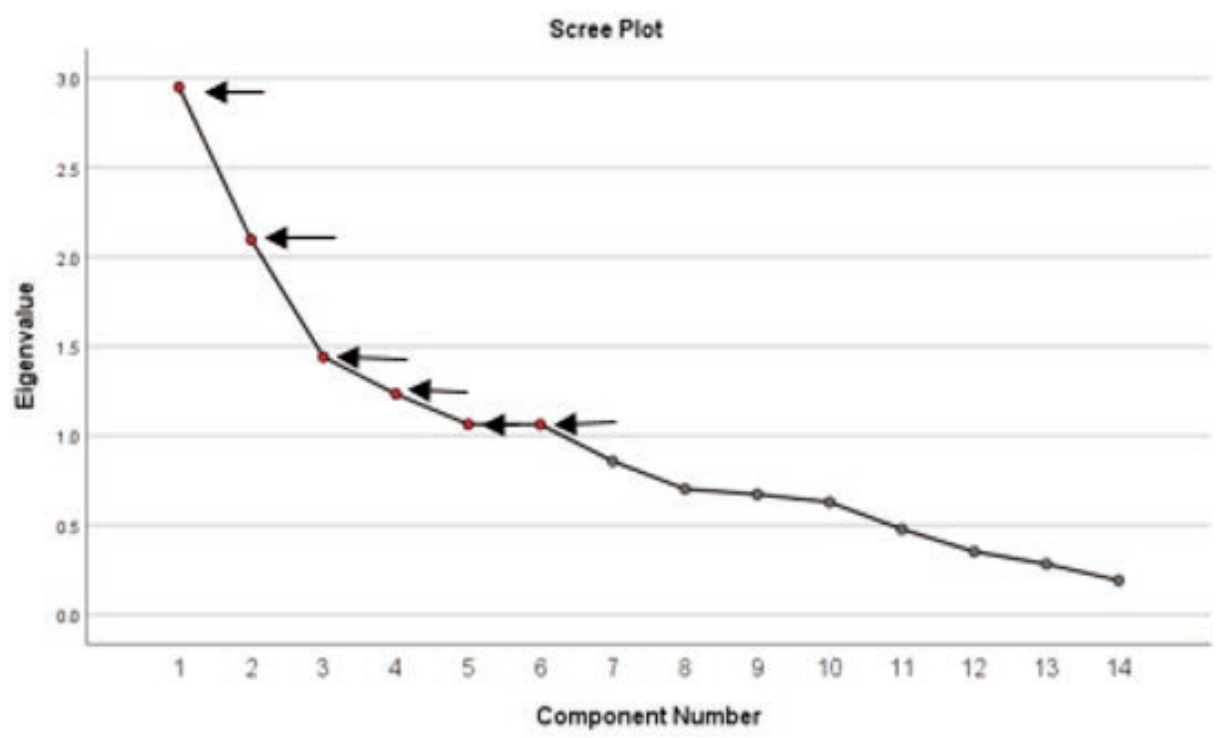

Figure 2: Scree plot Test suggests that six factors should be extracted

Table 8: Components matrix and loadings before rotation and after orthogonal rotation by the Varimax method, for the measured variables (The problems of irrigated vegetable)

\begin{tabular}{|c|c|c|c|c|c|c|c|c|c|c|c|c|}
\hline & \multicolumn{6}{|c|}{ Component Matrix $^{a}$} & \multicolumn{6}{|c|}{ Rotated Component Matrix ${ }^{\mathrm{a}}$} \\
\hline & \multicolumn{6}{|c|}{ Component } & \multicolumn{6}{|c|}{ Component } \\
\hline & 1 & 2 & 3 & 4 & 5 & 6 & 1 & 2 & 3 & 4 & 5 & 6 \\
\hline $\mathrm{x} 1$ & 0.462 & 0.479 & & $.597-$ & & & & 0.90 & & & & \\
\hline $\mathrm{x} 2$ & 0.556 & 0.487 & & & & & & 0.78 & & & & \\
\hline $\mathrm{x} 3$ & 0.506 & & & & & & & & & 0.6 & & \\
\hline $\mathrm{x} 4$ & 0.459 & & & & $.610-$ & & & & & 0.7 & & \\
\hline $\mathrm{x} 5$ & & & 0.503 & & $.405-$ & & & & & & & $.676-$ \\
\hline x6 & & 0.512 & & 0.586 & & & & & & & & 0.701 \\
\hline $\mathrm{x} 7$ & 0.438 & & & & 0.452 & & & & 0.6 & & & \\
\hline x9 & & & 0.679 & & & & & & & & 0.8 & \\
\hline $\mathrm{x} 10$ & & & 0.6 & & & 0.49 & & & & & 0.6 & \\
\hline $\mathrm{x} 11$ & & 0.431 & & & & & & & & & & \\
\hline $\mathrm{x} 12$ & 0.681 & & & & & $.415-$ & & & 0.7 & & & \\
\hline $\mathrm{x} 13$ & 0.691 & & & & & & & & 0.6 & & & \\
\hline $\mathrm{x} 14$ & & $.745-$ & & & & & 0.858 & & & & & \\
\hline $\mathrm{x} 15$ & 0.434 & $.734-$ & & & & & 0.909 & & & & & \\
\hline $\begin{array}{l}\text { - Ext } \\
\text { - a. } 6\end{array}$ & Metho & $\begin{array}{l}\text { Princip } \\
\text { tracted. }\end{array}$ & Comp & ient Ana & sis. & & $\begin{array}{l}\text { - Extr } \\
\text { - Rota } \\
\text { - a. Ro }\end{array}$ & $\begin{array}{l}\text { on } \mathrm{M} \\
\mathrm{Met} \\
\text { ion } \mathrm{cc}\end{array}$ & Vari & $\mathrm{Co}$ & nt A & $\begin{array}{l}\text { s. } \\
\text { tion. }\end{array}$ \\
\hline
\end{tabular}

Source: IBM Spss Statistics 26 Output /survey result 


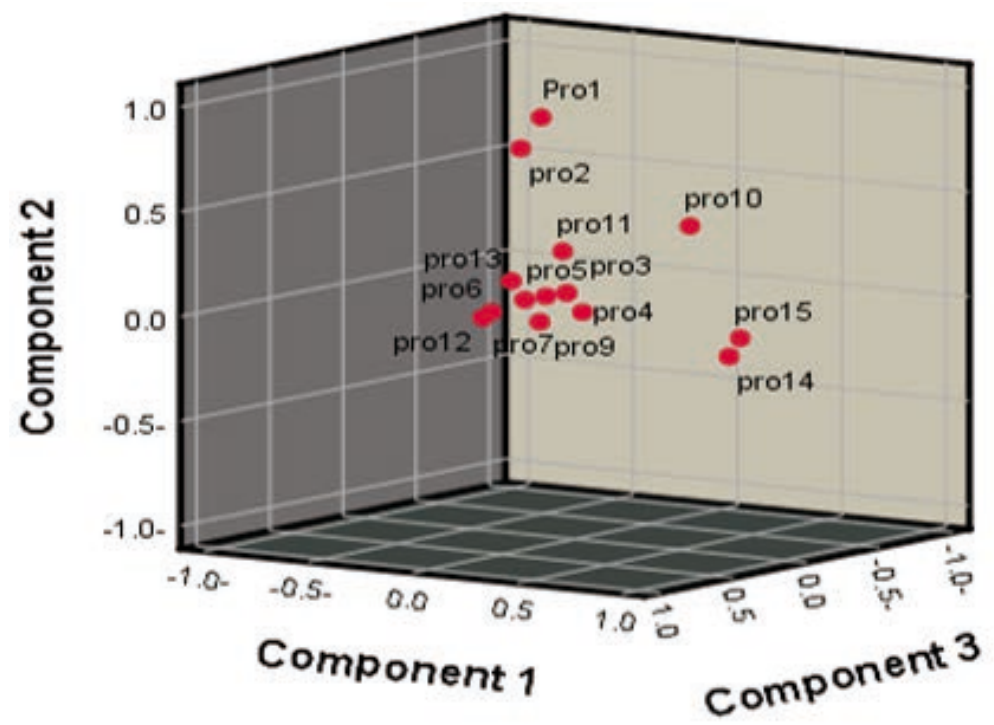

Figure 3: Component plot in rotated space

\subsubsection{The fourth step, naming the factors}

According to the results extracted from Table (8) above, the six identifying factors were named depending on the percentage of each load factor. All six factors included two determinants except for the third factor (the problem of sale outlets) which included three determinants. Table (9). The exploratory factor analysis technique was used to correspond to the assumptions in the concerning problems with the irrigated vegetable problems in Swaida Governorate, Syria during 20192020 Season, which directly effect on the production. The use of the exploratory factor analysis technique enabled the understanding of how variables are interrelated. It allowed the adjustment of the assessment instrument after the removal of variables with low indicators,

Table 9: The factors responsible for the largest proportion of the total variance in the production of irrigated vegetables projects

\begin{tabular}{|c|c|c|c|}
\hline Factor NO. & Name assigned to factor & $\begin{array}{l}\text { Determinants included } \\
\text { in Factor Analysis }\end{array}$ & Factor loadings $\%$ \\
\hline \multirow{2}{*}{ The first } & \multirow{2}{*}{$\begin{array}{l}\text { The problem of agricultural } \\
\text { technological progress. }\end{array}$} & $\begin{array}{l}\text { (X14): Providing farmers with the } \\
\text { necessary expertise }\end{array}$ & 0.858 \\
\hline & & $\begin{array}{l}\text { (15): Availability of information } \\
\text { about new technologies }\end{array}$ & 0.909 \\
\hline \multirow{2}{*}{ The second } & \multirow{2}{*}{$\begin{array}{l}\text { The problem of agricultural } \\
\text { employment. }\end{array}$} & (X1) Availability of manpower & 0.907 \\
\hline & & (X2) Labor efficiency & 0.789 \\
\hline \multirow{3}{*}{ The third } & \multirow{3}{*}{ The problem of sale outlets } & (X7) Effectiveness of Inputs & 0.605 \\
\hline & & (X12) disposing of the product & 0.791 \\
\hline & & $\begin{array}{l}\text { (X13) Availability of internal and external } \\
\text { markets }\end{array}$ & 0.624 \\
\hline \multirow{2}{*}{ The fourth } & \multirow{2}{*}{$\begin{array}{l}\text { The problem of natural } \\
\text { conditions }\end{array}$} & (X3) Infection with diseases and insects & 0.669 \\
\hline & & (X4) natural disasters & 0.772 \\
\hline \multirow{2}{*}{ The fifth } & \multirow{2}{*}{ The problem of prices } & (X9) Vegetable price fluctuations & 0.854 \\
\hline & & (X10) Brokers' control & 0.601 \\
\hline \multirow{2}{*}{ The sixth } & \multirow{2}{*}{$\begin{array}{l}\text { The problem of production } \\
\text { requirements }\end{array}$} & (X5) Availability of Inputs & 0.676 \\
\hline & & (X6) High costs of Inputs & 0.701 \\
\hline
\end{tabular}

Source: Depending on Table (8), survey results 
namely: [State support for production requirements $\mathrm{X}_{8}$ ] and [Low selling price $\mathrm{X}_{11}$ ]. Therefore, according to the results extracted from the exploratory factor analysis technique, using the Principal components methodology and Varimax rotation the six identifying factors with an initial Eigenvalues greater than one for each and depending on the percentage of each load factor were named: agricultural technological progress, agricultural employment, sale outlets, natural conditions, prices, production requirements. These factors explained $(13.21 \%, 12.65 \%$, $12.55 \%, 11.12 \%, 1.94 \%$, and $9.85 \%)$ of the total variance respectively, and together explained $70.33 \%$.

\section{CONCLUSIONS}

This research is unique because it showed the effectiveness of using the exploratory factor analysis methodology in identifying the most important factors responsible for explaining the largest percentage of the total variation in the production of irrigated vegetable projects in As-Swaida Governorate. The study recommends policy makers to addressing all the obstacles facing irrigated vegetable farming in Swaida Governorate in order to reduce their negative effects on the production process, like: marketing management through: preparing to purchase quantities of production directly from farmers, especially the surplus, establishing formal marketing offices to limit the control of brokers, concluding export deals with friendly neighboring countries, and setting minimum prices. Direct and indirect supervision of the production process through: supporting agricultural extension, intensifying agricultural courses related to modern agricultural technologies and marketing methods. Managing strict control, especially the quality of production requirements (seeds, fertilizers, irrigation water, pesticides....).

\section{REFERENCES}

Ahmadi, H., Rezaei, R., \& Kheiri, S. (2013). Factor analysis of barriers and problems affecting the development of nanotechnology in agriculture. Annals of Biological Research, 4(1), 131-134.

Anderson, T. W. (2003). An Introduction to Multivariate Statistical Analysis. Third Edition. John Wiley \& Suns, Inc. Huboken, New Jersey. p.747.

Cattell, R. B. (1966). The scree test for the number of factors.
Multivariate Behavioral Research, 1(2), 245-276. https://doi. org/10.1207/s15327906mbr0102_10

Chandrashekar, S., Bahal, R., \& V.P.H.D. (2012). Factors influencing the entrepreneurial behavior of agricultural graduates. SAARC Journal of Agriculture. 10(2), 31-39. https:// doi.org/10.3329/sja.v10i2.18321

Field, A. (2009). Discovering Statistics using Spss. 3th edition. London: SAGE publications Ltd. Singapore. p. 854.

Glenn, D. I. (1992). Determining Sample Size. Florida cooperative extension service. University of Florida. Fact sheet peod-6.

Harman, H. H. (1976). Modern Factor Analysis. Third edition. Revised. Chicago, University of Chicago Press. P. 508.

Hair, J. F. Jr., Black, W. C., Babin, B. J., \& Anderson, R. E. (2009). Multivariate Data Analysis. Seventh edition. Published by Pearson.

Mcdonald, R. P. (1985). Factor Analysis and Related Methods. Hillside, NJ: Lawrence Erlbaum associates, inc.

Ledesma, D. R., Mora, P. M. V., \& Macbeth, G. (2015). The scree test and the number of factors: a dynamic graphics approach. Spanish Journal of Psychology, 18(11), 1-10. https:// doi.org/10.1017/sjp.2015.13

Pavel, A. \& Octavian, M. (2019). Determining local economic development in the rural areas of Romania. Exploring the role of exogenous factor. Sustainability, 11, 282; DOI: 10.3390 / su11010282. https://doi.org/10.3390/su11010282

Pituch, K. A. \& Stevens, J. P. (2016). Applied Multivariate Statistics For The Social Sciences Analyses With SAS and SPSS. Sixth edition. Routledge (Taylor \& Francis group). New York and London.

Rezai, G., Shamsudin, M. N., \& Mohamed, Z. (2016). Urban agriculture: a way forward to food and nutrition security in Malaysia, Procedia - Social and Behavioral Sciences, 216, 39 - 45. https://doi.org/10.1016/j.sbspro.2015.12.006

Ministry of Agriculture and Agrarian Reform. Directorate of planning and international cooperation. Annual agricultural statistical abstracts (2016-2018). Damascus, Syria.

Ministry of Agriculture and Agrarian Reform. Directorate of agricultural extension unpublished data 2020. Swaida, Syria.

Tabachnik, B. G. \& Fidell, L. S. (2013). Using Multivariate Statistics. Sixth edition, Pearson education, Inc. New Jersey. USA. P.1018.

Tighza, M. B. (2012). Exploratory Factor Analysis and Confirmatory, Concepts and Methods Using Spss and LIREl. First edition. Dar Almasera. Aman, Jordan. P. 399

Thompson, B. (2004). Exploratory and Confirmatory Factor Analysis Understanding Concepts and Applications. American Psychological Association. P.185. https://doi. org/10.1037/10694-000

Yamane, T. (1967). An Introductory Analysis. Second edition. New York: Harper and Row.

Zeina, M. (2015). The important of exploratory factor analysis to achieve the factorial structure of psychological tests. Geel Journal of Social and Human Sciences, 14, 40-31. 
Appendix 1

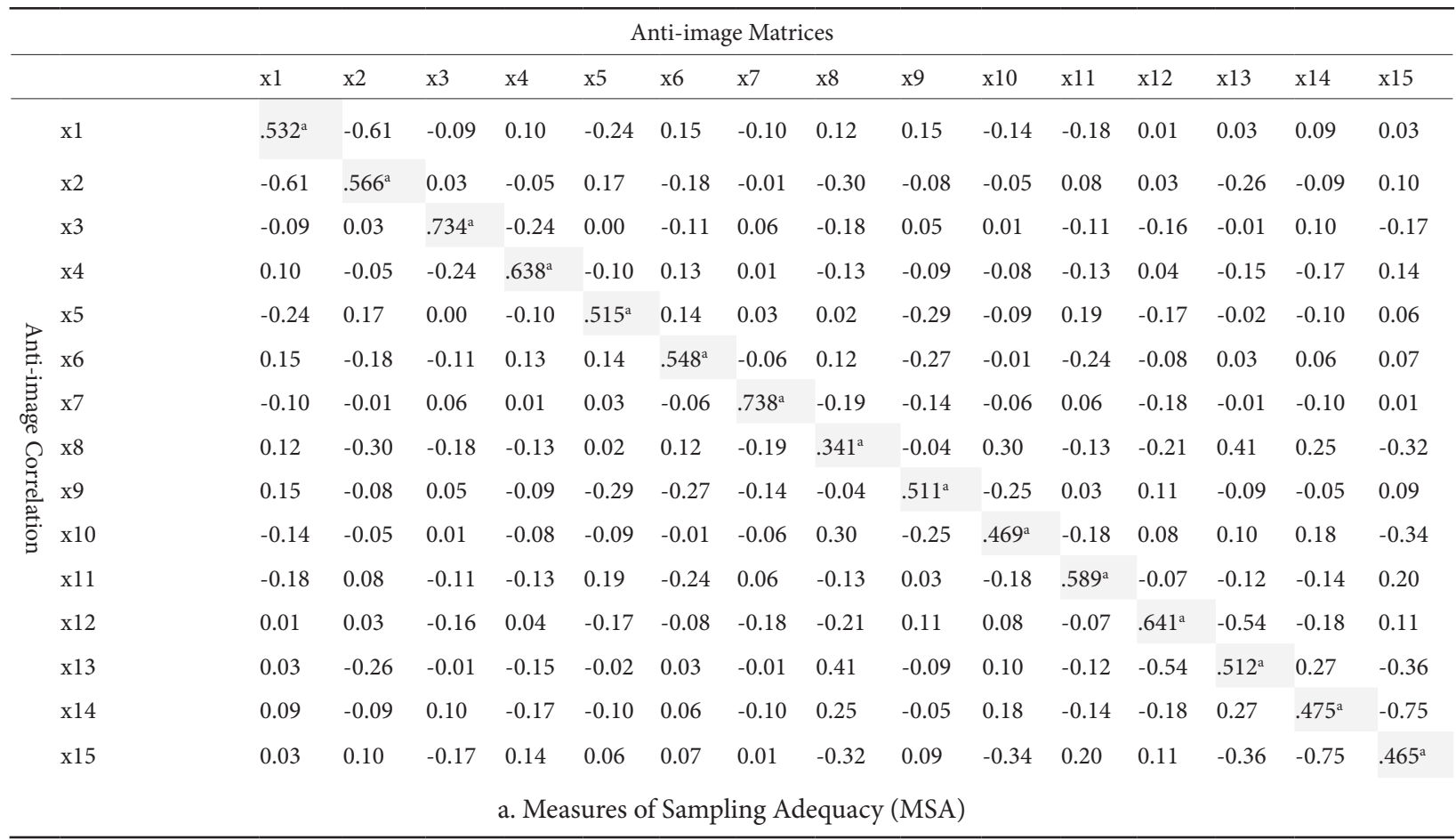

Source: IBM Spss Statistics 26 Output /survey result 